\title{
Physicochemical Characterization and Determination of Trace Metals in Sugar Manufactured from Sugar Cane
}

\author{
Desissa Yadata \\ Department of Chemistry, College of Natural and Computational Science, Mizan Tepi University, Ethiopia
}

Copyright (c) 2014 Horizon Research Publishing All rights reserved.

\begin{abstract}
The current study is interested in determination of trace metals in sugar originated from different sources such as soil, water. The analytical technique used in the study was atomic absorption spectroscopy and the results revealed that concentration of metals found in soil sample was; 51 $\mathrm{mg} / \mathrm{kg} \mathrm{Fe}, 6 \mathrm{mg} / \mathrm{kg} \mathrm{Mn}, 2.5 \mathrm{mg} / \mathrm{kg} \mathrm{Cu}, 0.36 \mathrm{mg} / \mathrm{kg} \mathrm{Cd}, 8.32$ $\mathrm{mg} / \mathrm{kg} \mathrm{Zn,} \mathrm{3.92mg/kg} \mathrm{Cr,} 5.4 \mathrm{mg} / \mathrm{kg} \mathrm{Ni}, 4.08 \mathrm{mg} / \mathrm{kg}$ Co and $0.28 \mathrm{mg} / \mathrm{kg} \mathrm{Ag}$. Concentration of metals found in sugar sample was $0.89 \mathrm{mg} / \mathrm{kg} \mathrm{Fe}, 0.28 \mathrm{mg} / \mathrm{kg} \mathrm{Mn}, 0.79 \mathrm{mg} / \mathrm{kg} \mathrm{Zn}$, $0.88 \mathrm{mg} / \mathrm{kg} \mathrm{Cr}, 0.61 \mathrm{mg} / \mathrm{kg} \mathrm{Ni}$, and $0.33 \mathrm{mg} / \mathrm{kg}$ Co. Concentration of copper, silver and cadmium was not detected. Concentration of metals found in effluent sample was $19.3 \mathrm{mg} / \mathrm{kg} \mathrm{Fe}, 2.5 \mathrm{mg} / \mathrm{kg} \mathrm{Mn}, 1.1 \mathrm{mg} / \mathrm{kg} \mathrm{Zn}, 1.39$ $\mathrm{mg} / \mathrm{kg} \mathrm{Cr}, 2.84 \mathrm{mg} / \mathrm{kg} \mathrm{Ni}, 1.6 \mathrm{mg} / \mathrm{kg}$ Co and $0.05 \mathrm{mg} / \mathrm{kg} \mathrm{Cd}$. The physicochemical characters such as biological oxygen demand, chemical oxygen demand, temperature, electrical conductivity and $\mathrm{pH}$ are determined to be significant. High concentration of trace metals was determined in soil in relative to other sample and sugar sample studied is safe for consumption.
\end{abstract}

Keywords Concentration, Downstream, Effluent, Sugar, Upstream

\section{Introduction}

The essential metals in trace levels play vital role when present in human body. Ions of transition metals essential for life include manganese, iron, nickel, cobalt, zinc, copper and chromium. Metals are useful for metabolic activities acting as catalyst. Trace metals are micronutrients required in trace levels in plants as well as animals. Micro level imply requirement only in small concentration [1].

Although trace metals are essential to life process they pose health problem if present in concentration that exceeds the permissive level. White sugar can contain some metals impurities depending on the quality of sugar cane used in its production technology. Contents of these metals in sugar cane are a function of physical and chemical nature of the soil as well as plants which absorb these metals from deposits on the parts of their roots by wet or dry deposition from polluted environment $[2,3]$.

Trace heavy metals like $\mathrm{Ag}$ and $\mathrm{Cd}$ can exist in association with macronutrients. This association can influence the proper work of the metals by pairing. The main source of toxicity now a day is food. Food processing methods are commonly responsible for the contamination of human food by toxic metals.

The maximum permissible level of toxic metals in human food has been established by the FAO/WHO expert committee on food additives recommended a provisional maximum tolerable daily intake for $\mathrm{Cd}, \mathrm{Co}, \mathrm{Ni}, \mathrm{Cu}$ and $\mathrm{Zn}$ from all sources of food, air, water 1-2,3.5-4,2-4,2-2.5 and $8-15 \mu \mathrm{g} / \mathrm{kg}$ of body mass respectively[4,5,6].

Sugar factory is one of the biggest factory manufacturing sugars for consumption of mankind. The factory uses fertilizers to produce sugar cane and chemicals to process cane juice. Hence at different stages of sugar processes there are chemicals in use that can contribute metal ions directly or indirectly to the sugar products. Therefore this study become prominent in exploring the level of metal ions and forwards the expected outcome.

The objective of the work is

- To determine the concentration of trace metals in sugar sample.

- To characterize effluents and river in terms of BOD, $\mathrm{COD}, \mathrm{pH}$, temperature, electrical conductivity and TDS.

The significance of the study is to add the information about the relationship between soil, river and effluents in accommodating metal ions.

\section{Materials and Methods}

\subsection{Instrumentation}

ELICO SL-194 India atomic absorption spectrophotometer (AAS), Hana pH meter (H18314 Japan), portable conductometry (handy play HF Japan), 101-0 Electric Heated Blast Dry Box Oven and SX-10 Box Resistance Furnace Controller Box and TDS meter. 


\subsection{Chemicals and Reagent}

Uni. Chem. Chemical reagents N29508-4K Con. $\mathrm{HNO}_{3}$ (assay 65-68\%) UN 1789 IATA 37\% HCl, H44 H47055-45 $30 \% \mathrm{H}_{2} \mathrm{O}_{2}, 2 \mathrm{ml}$ olive oil and stock solution of metal ions under study.

\subsection{Methodology}

\subsubsection{Soil Sampling}

Soil sample was collected from cultivated soil where sugar cane is planted and samples are collected from different points separated at some distance from each other. At each place soil sample has been taken at an average depth of $15 \mathrm{~cm}$ and totally $1 \mathrm{~kg}$ obtained from each point of collection. During collection soil sample was packed into aluminum foil of thickness $0.08 \mathrm{~mm}$ and preserved in ice bag until analysis $[7,8]$.

\subsubsection{Sugar Sampling}

Sugar samples were collected two times from the factory product and the total of $1 \mathrm{~kg}$ sugar sample was collected in each cases. The first sample was taken from the products manufactured within the first b15 days of the month whereas the second case was collected from the products manufactured within the second 15days of the month [8]. Different packages of the product were used during collection.

\subsubsection{Effluent Sampling}

Effluents were assigned to be collected from two positions with respect to sugar factory. The first position is at outlet (E1) and the second is at the point where effluent mix with river (E2). During collection polyethylene bottle was used which was rinsed with $\mathrm{HNO}_{3}$. After collection the sample was stored in refrigerator before any determination has been taken place. Temperature, electrical conductivity, total dissolved solid, $\mathrm{pH}$, biological oxygen demand and chemical oxygen demand of the sample were determined before metal analysis has been performed [9].

\subsubsection{Water Sampling}

There were two positions of sample consideration when water sample collected. The first position is the river before effluent mixed and named to be upstream. The other option is the river part after effluent is added which was assigned to be downstream [10]. The apparatus used to collect sample is polyethylene which was rinsed with $\mathrm{HNO}_{3}$.

\subsection{Sample Preparation}

\subsubsection{Soil Sample Preparation}

The soil collected was placed in the oven at $85^{\circ} \mathrm{C}$ to be dried and then powdered to uniform particle size with mortar and pestle. The total soil sample taken for analysis was $2.5 \mathrm{~g}$ and this amount was dissolved in distilled water. The solution was mixed with mixture of $3 \mathrm{ml}$ of $0.02 \mathrm{~N} \mathrm{HNO}_{3}$ and
$\mathrm{H}_{2} \mathrm{O}_{2}$ and placed on hot plate for 25 minutes at $35^{\circ} \mathrm{C}$ [11].

\subsubsection{Sugar Sample Preparation}

The sugar sample was finely powdered with mortar and pestle in platinum dish. $7.5 \mathrm{~g}$ of the finely powdered sugar sample was placed in crucible. The crucible with sugar sample was placed in oven at $105^{\circ} \mathrm{C}$ for about 20 hours. After the sugar sample dried it was further placed in muffle furnace and ashed at $500^{\circ} \mathrm{C}$. The white ash formed was rinsed with deionized water and covered with watch glass and put on hot plate at $35^{\circ} \mathrm{C}$ without boiling and added $3 \mathrm{ml}$ of $0.02 \mathrm{~N} \mathrm{HNO}_{3}$. The sample was cooled for some time and reheated on hot plate. The watch glass has been opened to allow excess $\mathrm{HNO}_{3}$ to escape. Additional $5 \mathrm{ml}$ of $\mathrm{HNO}_{3}$ was added until digestion complete. The sample was heated after further cooling and the mixture of water and $\mathrm{HCl}$ in the ratio of 50:50 was added and reheated [12].

\subsubsection{Effluent Sample Preparation}

The effluent sample was taken into $250 \mathrm{ml}$ beaker and added $3 \mathrm{ml}$ of $0.02 \mathrm{~N} \mathrm{HNO}_{3}$ and covered with watch glass to heat gently on hot plate at $35^{\circ} \mathrm{C}$ without boiling. The sample was cooled and another $3 \mathrm{ml}$ of $\mathrm{HNO}_{3}$ was added and placed on hot plate and reheated at $35^{\circ} \mathrm{C}$. Repeatedly cooling and heating has been taken place until digestion completes [13].

\subsubsection{Water Sample Preparation}

The water sample was filtered with what man filter paper № $42.100 \mathrm{ml}$ of the filtrate was measured and added into $250 \mathrm{ml}$ beaker. Into the beaker $3 \mathrm{ml}$ of $\mathrm{HNO}_{3}$ was added and placed on hot plate at $35^{\circ} \mathrm{C}$. The beaker was covered with watch glass and heated gently. The watch glass was removed to avoid excess $\mathrm{HNO}_{3}$. After some time the mixture of $\mathrm{HCl}$ and $\mathrm{HClO}_{4}$ was added to dissolve any precipitate in the sample and lastly the sample was filtered [14].

\subsection{Determination of BOD}

The effluent sample was neutralized to $\mathrm{pH} 7.2$ by adding $3 \mathrm{ml}$ of $0.1 \mathrm{~N} \mathrm{NaOH}$. For BOD measurement two half filled $300 \mathrm{ml}$ bottle with dilution water were prepared. One of the bottles for each sample dilution and the one with dilution water was incubated for five days at $20^{\circ} \mathrm{C} \pm 1$. DO determination was applied before incubation and after incubation. After five days the remaining DO was measured [15].

$=\frac{\begin{array}{c}\frac{m g}{L}, \text { BOD } 5 \\ \text { initial DO of diluted sample }- \text { DO of sample after five days }\end{array}}{\text { Percentage of sample added into incubator }} \times 100$

\subsection{Determination of COD}

For the determination of COD $45 \mathrm{ml}$ of the sample was taken into $250 \mathrm{ml}$ volumetric flask and $1.5 \mathrm{ml}$ of potassium dichromate was added in the flask. The mixture was refluxed for 6hours, cooled and excess dichromate solution was 
titrated with $0.1 \mathrm{~N}$ Mohr salt. The remaining excess dichromate revealed the consumed amount of COD [16].

\subsection{Determination of $\mathbf{p H}$}

The electrode was calibrated with buffer solution at $\mathrm{pH}$ of 4 and 9 . The calibrated electrode was rinsed with deionized water and wiped with a tissue paper; finally the electrode was immersed in sample solution of unknown $\mathrm{pH}$.

\subsection{Metal Analysis}

Metals were determined typically by flame atomic absorption spectrophotometer. Atomic absorption spectrophotometer (FAAS) analyses are utilized for the determination of $\mathrm{Ag}, \mathrm{Cd}, \mathrm{Co}, \mathrm{Cr}, \mathrm{Cu}, \mathrm{Fe}, \mathrm{Mn}, \mathrm{Ni}$ and $\mathrm{Zn}$.

Calibration curve was established using standard solution of each metal ion. The stock solution of the metal ion was prepared in $0.02 \mathrm{~N} \mathrm{HNO}_{3} .1000 \mathrm{mg} / \mathrm{L}$ of each metal ion was prepared by weighing $1 \mathrm{~g}$ of each metal ion and dissolve in water and further mixed with $\mathrm{HNO}_{3}$ prepared from $2 \mathrm{ml}$ of $68 \%$ assay dissolved in $100 \mathrm{ml}$ distilled water. Working solution was prepared by measuring $1 \mathrm{ml}$ of stock solution in order to prepare range of concentration [17].

\section{Results and Discussion}

Method validation: to validate the analytical performance of the instrumental analysis the determination of instrument and method detection limit, the analysis of initial and continuing calibration standards, Laboratory Fortified Blank (LFB) and LFB duplicate Analysis, and Laboratory Fortified Matrix (LFM) and LFM duplicate Analysis were done for each analyte.

From table 3 the $\mathrm{pH}$ of cane wash, mill house, boiling house, upstream and downstream was 7.15, 6, 6.06, 6.93 and 6.92 respectively. The results indicated that the $\mathrm{pH}$ of cane wash, upstream and downstream samples was nearly neutral. Millhouse and boiling house were slightly acidic. The upstream and downstream water samples exhibited similar $\mathrm{pH}$ value. The acidity of effluents such as mill house and boiling is because of the fact that sucrose decompose into monosaccharide, organic acids and alcohols [17].

Table 1. Instrument optimized condition for specific metals

\begin{tabular}{|c|c|c|c|c|c|c|c|c|c|}
\hline Metal & $\mathrm{Ag}$ & $\mathrm{Cd}$ & $\mathrm{Ni}$ & $\mathrm{Mn}$ & $\mathrm{Co}$ & $\mathrm{Zn}$ & $\mathrm{Fe}$ & $\mathrm{Cr}$ & $\mathrm{Cu}$ \\
\hline Wavelength(nm) & 328.1 & 228.8 & 232 & 279.8 & 240.7 & 213.9 & 248.3 & 357.9 & 324.7 \\
\hline Slit width(nm) & 1 & 1.5 & 2.5 & 2.5 & 2.5 & 1.5 & 2.5 & 0.75 & 1 \\
\hline Current(Ma) & 04.4 & 05.4 & 06.6 & 05.5 & 07 & 06.4 & 06.4 & 05 & 06.4 \\
\hline
\end{tabular}

Table 2. Regression equations, correlation coefficients and detection limits

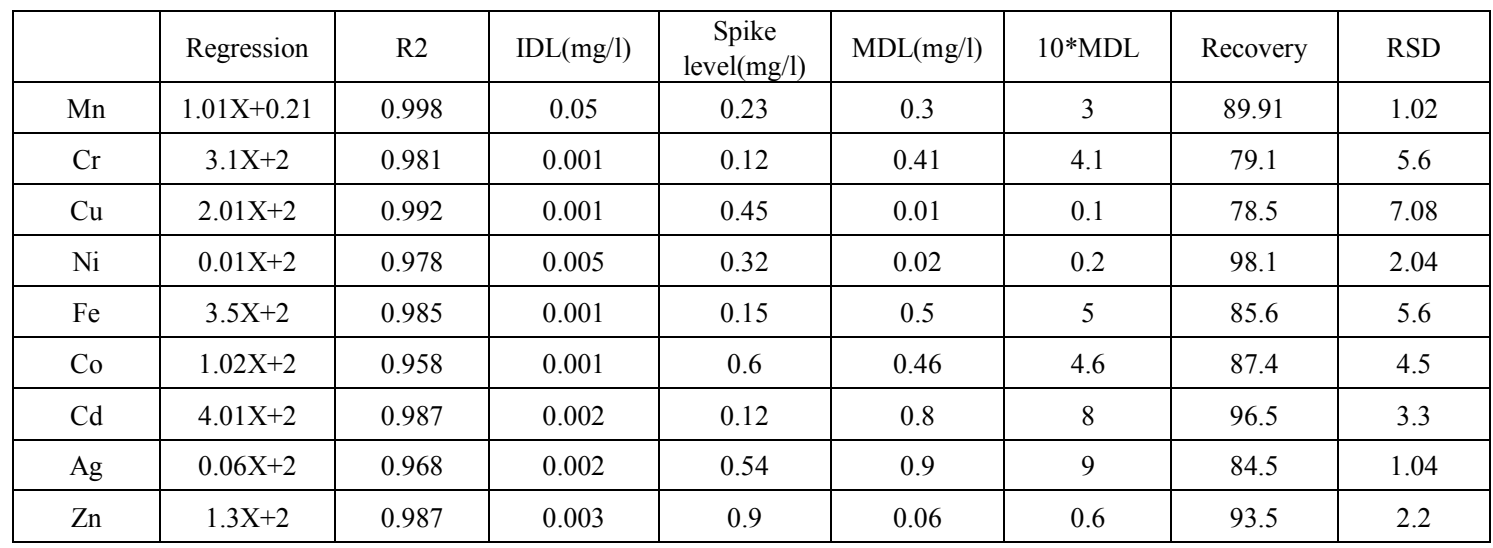

Table 3. Physico chemical characteristics of effluent and water sample

\begin{tabular}{|c|c|c|c|c|c|c|}
\hline Effluent type & $\mathrm{pH}$ & $\begin{array}{c}\text { Electrical } \\
\text { conductivity }\end{array}$ & $\mathrm{T}\left({ }^{\circ} \mathrm{C}\right)$ & $\mathrm{TDS}$ & $\mathrm{BOD}$ & $\mathrm{COD}$ \\
\hline Cane wash & $7.15 \pm 0.0057$ & $0.16 \pm 0.014$ & $30 \pm 1$ & $105 \pm 1$ & $40 \pm 1$ & $105 \pm 2.5$ \\
\hline Mill house & $6 \pm 1$ & $0.395 \pm 0.007$ & $40 \pm 1$ & $220 \pm 1$ & $1596 \pm 11$ & $4600 \pm 100$ \\
\hline Boiling house & $6.06 \pm 0.5$ & $0.6 \pm 0.1$ & $42 \pm 1$ & $360 \pm 10$ & $1506 \pm 11$ & $16789 \pm 105$ \\
\hline Up stream & $6.93 \pm 0.01$ & $0.07 \pm 0.01$ & $22 \pm 1$ & $49 \pm 0.1$ & $50 \pm 1$ & $44 \pm 0.1$ \\
\hline Down stream & $6.92 \pm 0.01$ & $0.09 \pm 0.1$ & $26 \pm 1$ & $50 \pm 0.1$ & $59 \pm 1$ & $56 \pm 0.04$ \\
\hline
\end{tabular}


Table 4. Concentration of trace metals in different samples of sugar effluent, water and soil

\begin{tabular}{|c|c|c|c|c|c|c|c|}
\hline Metals & E1 & E2 & Upstream & Down stream & Soil & Sugar & WHO \\
\hline $\mathrm{Cu}$ & $\mathrm{ND}$ & $\mathrm{ND}$ & $0.08 \pm 0.01$ & $0.14 \pm 0.01$ & $2.8 \pm 0.26$ & $\mathrm{ND}$ & 0.1 \\
\hline $\mathrm{Cd}$ & $0.5 \pm 0.25$ & $0.42 \pm 0.03$ & $0.24 \pm 0.02$ & $0.14 \pm 0.01$ & $0.36 \pm 0.03$ & $\mathrm{ND}$ & 0.007 \\
\hline $\mathrm{Zn}$ & $1.12 \pm 0.41$ & $0.3 \pm 0.01$ & $0.3 \pm 0.045$ & $0.46 \pm 0.01$ & $8.55 \pm 0.2$ & $0.81 \pm 0.03$ & 0.5 \\
\hline $\mathrm{Cr}$ & $1.35 \pm 0.05$ & $1.09 \pm 0.1$ & $0.43 \pm 0.03$ & $1.14 \pm 0.05$ & $3.95 \pm 0.04$ & $0.8 \pm 0.072$ & 0.05 \\
\hline $\mathrm{Ni}$ & $2.75 \pm 0.46$ & $2.64 \pm 0.08$ & $1.6 \pm 0.1$ & $1.75 \pm 0.13$ & $5.4 \pm 0.1$ & $0.64 \pm 0.026$ & 0.01 \\
\hline $\mathrm{Fe}$ & $20.61 \pm 1.67$ & $16.25 \pm 0.35$ & $10.72 \pm 0.23$ & $18.2 \pm 0.72$ & $51 \pm 6.55$ & $0.9 \pm 0.07$ & 0.3 \\
\hline $\mathrm{Mn}$ & $2.5 \pm 0.42$ & $2.3 \pm 0.01$ & $0.67 \pm 0.046$ & $1.3 \pm 0.09$ & $0.75 \pm 0.12$ & $0.293 \pm 0.06$ & 0.05 \\
\hline $\mathrm{Co}$ & $1.65 \pm 0.2$ & $0.453 \pm 0.045$ & $0.416 \pm 0.03$ & $1.2 \pm 0.1$ & $4.12 \pm 0.15$ & $0.33 \pm 0.01$ & 0.3 \\
\hline $\mathrm{Ag}$ & $\mathrm{ND}$ & $\mathrm{ND}$ & $\mathrm{ND}$ & $\mathrm{ND}$ & $0.31 \pm 0.04$ & $\mathrm{ND}$ & - \\
\hline
\end{tabular}

ND-not detected, E1-effluent without water, E2-effluent and water

Total dissolved solid (TDS): it increases with increasing temperature since most solids dissolve faster as temperature increase. Cationic species favors acidic media and hence amount of dissolved mater increase in the millhouse and boiling house [17].

Electrical conductivity (EC): the electrical conductivity was determined to be $0.09-0.15 \mathrm{mS} / \mathrm{cm}$. the conductivity is directly related o the dissolved solutes and ions. The results indicated that effluents in process revealed more electrical conductivity than the other cases. It is because chemical processes emerged and taken place so as to release more ions and soluble solutes [18].

Temperature: according to the study in table 3 cane wash effluent temperature is less than millhouse and boiling house. The step where exchange of heat energy and occurrence of chemical reactions such as decomposition expected to take place in millhouse and boiling house [18].The temperature of water sample obtained from the river determined to be lower than any of the sample analyzed.

Biological oxygen demand (BOD) and Chemical oxygen demand (COD): of millhouse and boiling house determined to be higher compared to the other samples. BOD is biologically active species available during the process; therefore it indicates that microorganisms activating decomposition reaction were more than the other three samples. COD is oxygen demanding chemicals for oxidation; hence there are different organic compounds require oxygen for further oxidation processes. In upstream, downstream and cane wash the value of BOD and COD was determined to be lower since no significant chemical processes involving decomposition taken place [16].

The concentration of copper in E1, E2 and sugar sample was not detected and indicated as not detected. The concentration of silver is also not detected in all the cases and only significant to be detected in soil sample. The concentration of cadmium is negligible in sugar sample and not detected. In the other metal ions significant amount is detected and compared among samples.

The concentration of metal ions determined in downstream was greater than that of upstream. This was explained in terms of the fact that the river was exposed to further metal ions in effluent released from the factory processing stages during sugar manufacturing [17]. The concentration of some of the metal ions varied among effluent at the factory (E1) and effluent at the gate to the river (E2). According to the comparison the concentration of $\mathrm{Cd}$, $\mathrm{Zn}, \mathrm{Cr}, \mathrm{Ni}, \mathrm{Fe}, \mathrm{Mn}$ and $\mathrm{Co}$ in $\mathrm{E} 1$ was greater than in case of E2. It was because concentration expressed as amount per diluting solvent; as the effluent move longer and longer along the river; the amount of metal ions added to more water. Except in case of cadmium the concentration of metal ion in soil exceeded the concentration in the other sample [16]. The concentration of all the metals determined in sugar is less than any of sample analyzed; since sugar is the final product passed through different refining and purification stages [18]. Thus soil contributes more of the metal ions to sugar from plantation to production stage through direct or indirect influence.

The concentration of $\mathrm{Cd}, \mathrm{Cr}, \mathrm{Ni}, \mathrm{Fe}$ and $\mathrm{Mn}$ in sugar effluents exceeded the concentration established according to EPA.

\section{Conclusions}

Sugar is the product obtained from sugar cane after several factory processes have been taken place. These different stages use additives at several steps for production, purification, extraction and bleaching. At each of the stages there are main products and byproducts. The BOD, COD and TDS of millhouse and boiling house effluent was determined to be greater than the three cases cane wash, upstream and downstream. According to the current study the source of metal ions in sugar was determined to be from the soil and rarely from irrigation. The concentration of some metals was determined to be greater than EPA standards established for industry effluents. The concentration in sugar sample was almost safe in relative to world health organization.

\section{Acknowledgements}

Firstly I would like to express my most appreciation to almighty GOD for his help in spiritual and moral hope. 
Secondly my appreciation is to Mizan Tepi University for accessing materials, laboratory rooms and lab technician.

\section{REFERENCES}

[1] Sena, R.K (2004). Essential trace metals in human whole blood in relative to environment university press, journal of medicine and research Pakistan 43(2) 54-78

[2] Bell S., (2003). Environmental protection on determination of heavy metals in beet sugar. environmental protection and protection, Yugoslavia 4(3) 657-661

[3] United States, (1993) Environmental protection agency. Sample handling and preservation in methods for chemical analysis of water and wastes.

[4] Chaudhary, M.J. (2006). quality of effluents from Hattar industrial estate earth Hattar, environmental science Pakistan 7(12), 45-67

[5] Kuck K. (1998). Extraction procedures for metal analysis in soil; institute of medical research and computational health. Croatia 49(4), 327-334

[6] Juliano T., Jose M. (2008). Environmental evaluation of metals in sediments and dragon flies due to sugar cane cultivation in geotropically streams, Environmental pollution 195(3) 1-4

[7] Schipper T. (2005). Solid solution partitioning of heavy metals in food plain soils of the rivers Rhine and Meuse by field sampling and geochemical modeling $\mathrm{PhD}$ thesis Wagenign university

[8] Anderson M. (2002). Management effects on nitrogen recovery in sugar cane crop grown Brazil. Soil science, 166, $1829-1935$

[9] Biggs S. (2004) ${ }^{15}$ nitrogen abundance studies in Australian commercial sugar cane. Plant soil. 238,21-30

[10] James R. (2008). Study on combined effluents; sustainable development policy institute 8, 2-4

[11] S. Rengaraj (2001) removal of chromium from water and waste water by ion exchanger resins. Hazard matter, vol.87,273-287

[12] Umbese C. (2008). Impact of combined industrial effluent on metal accumulation nitrate reductace activity and yield of two cultivators of Virginia. Environmental science and technology, volume 4, 1-5

[13] Anderson M. (2006). Essentials of ecology and environmental science second edition India 123-145

[14] V.K.Gupta and I. Ali, (2000), utilization of bagasse fly ash (a sugar industry) for the removal of copper and zinc from waste water. Purification Technology, volume 18, pp.131-328

[15] Ali and Gupta (2007), Advances in water treatment by adsorption technology, natural protocol

[16] Ferreira and M.A.Z. (2004), use of modified rice husks as a natural solid adsorbents of trace metals: characteristics and development of an on line pre concentration system for cadmium and lead determination by FAAS. Micro chemicals, volume $77,163-175$

[17] PM Odira (2008), anaerobic treatment of cane sugar effluent from Muhoroni. Civil engineering research and practice, volume $5,65-86$

[18] R.M. Awadallah (1995), Determination of trace metals in Egyptian sugar cane. Radio analytical and nuclear chemistry, volume 1, 49-64 